\title{
Factors Influencing County Commissioners' Decisions about Burn Bans in the Southern Plains, USA
}

\author{
Thomas W. McDaniel ${ }^{1}$, Carissa L. Wonkka ${ }^{2, *}$, Morgan L. Treadwell ${ }^{3} \mathbb{D}$ and Urs P. Kreuter ${ }^{1}$ (D) \\ 1 Ecology and Conservation Biology, Texas A\&M University, College Station, TX 77843, USA; \\ willifordmcdaniel@gmail.com (T.W.M.); urs@tamu.edu (U.P.K.) \\ 2 Northern Plains Agricultural Research Laboratory, USDA Agricultural Research Service, \\ Sidney, MT 59270, USA \\ 3 Range, Wildlife and Fisheries Management Department, Texas A\&M AgriLife Extension Service, \\ San Angelo, TX 76901, USA; Morgan.Treadwell@ag.tamu.edu \\ * Correspondence: carissa.wonkka@usda.gov
}

Citation: McDaniel, T.W.; Wonkka C.L.; Treadwell, M.L.; Kreuter, U.P.

Factors Influencing County

Commissioners' Decisions about Burn Bans in the Southern Plains, USA. Land 2021, 10, 686. https:// doi.org/10.3390/land10070686

Academic Editors: Nathan F. Sayre and Lea Wittenberg

Received: 1 May 2021

Accepted: 24 June 2021

Published: 30 June 2021

Publisher's Note: MDPI stays neutral with regard to jurisdictional claims in published maps and institutional affiliations.

Copyright: (C) 2021 by the authors Licensee MDPI, Basel, Switzerland. This article is an open access article distributed under the terms and conditions of the Creative Commons Attribution (CC BY) license (https:// creativecommons.org/licenses/by/ $4.0 /)$.

\begin{abstract}
Woody plant encroachment in North American rangelands has led to calls for greater use of prescribed fire to reduce fuel loads and restore grazing productivity and grassland biodiversity. However, the use of prescribed fire during periods when woody plant mortality is maximized has often been limited by temporary restrictions on outdoor burning enacted by regional or local governmental entities. This study reports the results of a survey assessing the familiarity with and attitudes toward prescribed fire in Texas and Oklahoma, USA, of officials tasked with implementing restrictions on outdoor burning and how these attitudes influence their decisions. Most responding officials considered prescribed fire to be a safe and beneficial land management tool that should be used more frequently. Self-reported familiarity with prescribed fire was the most significant explanatory variable for this attitude. Further, familiarity with prescribed fire was influenced by respondent participation in or being invited to participate in a prescribed fire. Such invitations came mostly from private landowners. Landowners wishing to use prescribed fire may benefit from building trust with local officials by demonstrating they are qualified to conduct such fires safely. This could help reduce the frequency of burn restrictions and may increase the likelihood that officials will grant burn ban exemptions to qualified burn managers. Additionally, because officials' primary sources of prescribed fire information were reported to be local fire departments and emergency services, educating those entities about the benefits of prescribed fire for reducing wildfire risks could help reduce pressure on officials to enact or maintain burning restrictions. These findings highlight opportunities for reducing the frequency of burning restrictions, increasing opportunities for land managers to effectively halt or reverse woody plant encroachment.
\end{abstract}

Keywords: fire policy; fuel load reduction; legal liability; prescribed fire; rangeland management

\section{Introduction}

The Great Plains of North America were historically maintained as open grasslands by periodic fires and grazing by large herds of grazers [1,2] However, the widespread suppression of historical fire regimes together with land subdivisions in rural areas have catalyzed the proliferation of woody plants across many grassland landscapes, especially in the Southern Plains [3]. Rapid woody plant expansion (WPE), notably by Juniperus species (J. virginiana, J. ashei, and J. pinchotii), across the Southern Plains has compromised the habitats of many grassland species and lowered biodiversity across many locales [4,5]. WPE has also resulted in monetary losses for ranchers through reduced grazing productivity and fuel load accumulation that has led to a shift away from a regime dominated by relatively frequent and mild grass fires toward ecosystems with less frequent but more widespread and difficult to control wildfires [6,7]. 
Prescribed fire is the intentional application of fire to a landscape under specified conditions [8]. This offers land managers a rapid, inexpensive and ecologically beneficial land management tool to restore grasslands impacted by WPE $[8,9]$. One of the challenges facing land managers seeking to use prescribed fire is the enactment of outdoor burning restrictions. These burning restrictions, called burn bans in the Southern Plains of Texas and Oklahoma, USA, are enacted at a local (county) level and are commonly put in place during droughts or hot, dry periods when wildfire risk is deemed to be high. They typically consist of the prohibition of all outdoor fires and strict regulations of activities that can lead to an accidental fire [10]. Burn bans severely limit the ability of land managers to apply prescribed fire for grassland restoration under conditions that are conducive for high-intensity fires needed to substantially reduce the density of woody plants [11,12].

The impact of burn bans on prescribed burners differs among states. The Texas Prescribed Burning Bill of 1999 allows insured and certified burn managers to use prescribed fire during burn bans, but these qualifications can be difficult to maintain due to a lack of available insurance and the threshold of required experience [13-15]. County Commissioners' Courts, the official governmental entities responsible for implementing burn bans in Texas, can require the burn boss to acquire additional permits or to submit their burn plan for approval [16]. By contrast, burn bans are less restrictive to prescribed fire use in Oklahoma. In that state, burn managers only need to write a burn plan approved by their local fire department, keep a copy of the plan on-site during the prescribed fire, and inform local law enforcement and the fire department's dispatch center of the day and time the prescribed fire will be applied [17]. If the prescribed fire is to be applied within a protected area, then the nearest representative of the Forestry Division of the Oklahoma Department of Agriculture, Food, and Forestry also needs to be informed. Exemptions do not apply to a burn ban placed by the Governor in either state nor do they apply to burning for non-agricultural purposes, such as campfires or waste disposal [18].

County Commissioners (hereafter referred to as Commissioners) are elected public officials whose responsibilities in Texas and Oklahoma include the implementation and repeal of countywide bans on outdoor burning [19]. While burn bans are a prudent measure for preventing reckless or accidental ignition of wildfires, they can also be a source of frustration for landowners seeking to implement prescribed fire under conditions that are most effective for achieving woody plant mortality and restoring areas impacted by WPE. Prescribed fire has gained acceptance as a land-management tool in some regions [19-21]. However, in many areas, a large proportion of the public is unfamiliar with prescribed fire and perceives it to be highly risky or ecologically harmful [22-26]. This stigma can result from sensationalist media portrayals of wildfire and long-term anti-fire campaigns, such as Smokey Bear, making people uncomfortable with the deliberate ignition of fire for land management purposes [25]. As elected officials, some Commissioners may feel pressure from their constituents to enforce burn bans strictly, either due to recent wildfires sensationalized by the media or general public anxiety regarding prescribed fire safety $[9,22,26]$. Greater familiarity among Commissioners with the ecological benefits of prescribed fire and its importance for restoring grassland ecosystems and for reducing fuel loads in order to reduce wildfire risk might provide a counterbalance to public pressure to curtail the use of prescribed fire. However, this possibility has not been assessed to date.

Here, we investigate factors affecting Texas and Oklahoma Commissioners' decisionmaking regarding prescribed fire. Our objectives are as follows: (1) determine factors that influence Commissioners' decisions to enact burn bans; (2) identify criteria they use to make those decisions; (3) determine whether their comfort level with prescribed fire plays a role; (4) determine if a shift from simple to gross negligence would lead to more pressure to enact burn bans; and (5) determine if a shift to gross negligence would impact their decision to enact burn bans. 


\section{Study Area and Methodology}

\subsection{Study Region}

The study area comprised the Texas and Oklahoma segments of the Southern Plains, incorporating 202 and 69 counties in each state, respectively. The dominant land cover type of the Southern Plains has historically been semi-arid grassland, with shortgrass prairies in the west transitioning along the precipitation gradient to mixed prairies and tallgrass prairies in the east. These ecosystems are typically dominated by various species in the Poacea family. However, with prolonged fire suppression, large areas have become dominated by woody plants, particularly Juniperus spp. Together with conversion to cropland and widespread urbanization, WPE has contributed to the decline of native grasslands across the Great Plains. Less than $30 \%$ of the original grasslands remain, with highly arable tallgrass prairies comprising only $4 \%$ of their former range [27], while shortgrass (52\%) and mixed-grass (29\%) prairies have fared somewhat better but exist mainly as scattered patches imperiled by WPE [28].

\subsection{Study Design}

The study was based on a mail survey, which incorporated a questionnaire (designed using input from three stakeholder focus groups in both Texas and Oklahoma) to investigate the self-reported knowledge and attitudes of Commissioners about prescribed fire and its use within their jurisdictions. The survey sample was derived from all Commissioners in the 202 Texas counties and 69 Oklahoma counties falling within the Southern Plains ecoregion. A total of 300 Commissioners from Texas and 100 Commissioners from Oklahoma were selected for the study, representing a total survey sample of 400 . The weighted sample size was based on the larger population of Commissioners in Texas (1016) compared to Oklahoma (231) and the intent to maintain this proportion in the sample. The sample of Commissioners who would receive the survey was determined by randomly selecting one Commissioner from each Texas county and two Commissioners from each Oklahoma county in the study area. We then randomly selected additional Commissioners from the total pool of Commissioners in the study area in each state until the target numbers were reached; we set a stipulation that no more than two Commissioners could be selected from each county to assure that the sample was broadly representative. The survey sample distribution (75\% in Texas and 25\% in Oklahoma) approximated the proportion of Commissioners in the counties selected for the study ( $80 \%$ in Texas and $20 \%$ in Oklahoma). The mail survey was conducted during May-July 2018 using a four-phase mailing protocol [29], which included a pre-survey notification mailed on day 1 of the survey period; the survey questionnaire with a cover letter on day 7; a reminder card on day 21; and a replacement survey questionnaire with another letter on day 42. A copy of the survey is included in the Supplementary Materials (Supplementary document S1).

In addition to the main survey, a non-response survey was conducted by sending a one-page questionnaire to all of the selected Commissioners who did not complete and return the initial questionnaire. The second questionnaire included seven analyzable questions. The first asked why they had not participated in the study, and the others were the same as six key questions in the initial questionnaire. This allowed pair-wise comparisons of responses from survey participants and non-respondents to determine if there were any significant differences between the two groups.

\subsection{Statistical Analyses}

Data from the returned questionnaires were coded to numerical values and digitized. Descriptive statistics (median, mean, and standard deviation) were derived for all response variables, and frequency distributions were calculated for the results of categorical variables. Missing data were imputed via multivariate imputation by chained equations to obtain values for missing data when responses to a particular question were absent. We obtained five complete data sets via imputation. A separate model was fit for each variable with missing values. We used predictive means matching for numeric variables, proportional 
odds models for ordered logistic variables, and logistic models for binary variables. The missing data were assumed to be missing at random, an assumption that appears plausible from the distribution of missing responses. We dropped participants from the imputation and subsequent analysis if they left $>40 \%$ of the survey questions unanswered. In addition, we removed a variable from the imputation and subsequent analyses if $>10 \%$ of the respondents left that response blank. We also removed several variables that prevented convergence of multiple imputation models because of collinearity. We combined the estimates from the five imputed data sets by pooling the estimates of the complete data models, computing the variance over the repeated analyses by Rubin's rules [30]. We calculated degrees of freedom for the pooled estimates employing the Barnard-Rubin adjustment [31].

The five objectives were explored using Fisher's exact test for assessing differences in responses between states, logistic regression for binary dependent variables, ordered logistic regression via proportional odds models for ordered categorical dependent variables, and tests for simultaneous pairwise marginal independence for multiple response categorical dependent variables. When assessing simultaneous marginal independence, we applied a Rao-Scott approach to calculate modified Pearson statistics; this approach applies a second-order adjustment to the modified Pearson statistic and its sampling distribution (see [32] for equations associated with this method). We used this approach because it is thought to be more conservative than a non-parametric bootstrap approximation of the modified Pearson statistic [32]. All analyses were carried out in the R statistical computing environment [33], using the mice package for multiple imputations [34], the MASS package for proportional odds modeling [35], and the MRCV package for testing independence among multiple response categorical variables [36].

\section{Results}

\subsection{Response Rate and Non-Response Bias}

Of the 400 County Commissions selected for the study, 124 returned questionnaires, representing an overall response rate of $31 \%$, with $27 \%$ and $44 \%$ response rates from Texas and Oklahoma, respectively. Two additional respondents were excluded from the analysis because they left $>40 \%$ of the survey questions unanswered. Additionally, of the 278 Commissioners who did not participate in the study, 55 (19.8\%) completed the non-response questionnaire. The reasons non-respondents indicated they did not participate in the study included insufficient knowledge to complete the questionnaire $(41.8 \%)$, not enough time $(12.7 \%)$, sent the questionnaire back but we did not receive it $(7.3 \%)$, did not understand some of the questions (3.6\%), did not feel the need to participate (3.6\%), did not believe the study was confidential (1.8\%), and other reasons or no reason given (30.9\%). The nonresponse bias analysis indicated that respondents were more likely than non-respondents to have a high self-reported familiarity with prescribed fire ( $29 \%$ of respondents compared to $9 \%$ of non-respondents reported being "very familiar"; $t=6.12, p<0.001$ ), more time spent on fire-related issues ( $8 \%$ of respondents reported having spent no time on fire-related issues compared to $29 \%$ of non-respondents; $t=7.62, p<0.001$ ), greater comfort with prescribed fire (32\% of the respondents reported the highest level of comfort compared to only $13 \%$ of non-respondents; $t=20.92, p<0.001$ ), and have participated or been invited to participate in a prescribed fire $(48 \%$ of respondents reported that they had participated in a prescribed fire compared to $27 \%$ of non-respondents; $\chi^{2}=7.40, p=0.025$ ). There was no significant difference between respondents and non-respondents regarding awareness of the amount of prescribed fire used in their jurisdiction $\left(\chi^{2}=3.27, p=0.20\right)$ and awareness of prescribed fire liability standards $\left(\chi^{2}=5.42, p=0.14\right)$. The results of the non-response bias analysis indicated that the respondents represent a subset of Commissioners with more direct exposure to and experience with prescribed fire than non-respondents. 


\subsection{Demographic Trends}

On average, the responding Commissioners were 61.2 years of age, had received about 3.2 years of post-high school education, and had held their office for 9.1 years. In addition, respondents were $90 \%$ male and $74 \%$ Caucasian, with $11 \%$ being of other ethnicities and $15 \%$ stating no ethnicity. Three-quarters ( $74 \%$ ) of the respondents owned rural land, and $89 \%$ of those who owned land actively engaged in woody plant management. The most common woody plant control method used by respondents on their land to clear woody plants was mechanical treatment at $89 \%$, followed by chemical treatment at $72 \%$, and prescribed fire at $49 \%$.

\subsection{Familiarity and Comfort with Prescribed Fire}

About half (52\%) of the respondents reported that they had been invited to participate or had participated in prescribed fire, and $47 \%$ of those respondents did so as a volunteer (Table 1); $70 \%$ of them did so with independent private landowners rather than a government agency or a Prescribed Burn Association member (Table 1). The most commonly used prescribed fire information sources used by respondents were the local fire department, fire chief, or emergency services (67\%), followed by State Forest Services (40\%) (Table 1).

Table 1. (A) The role in which respondents reported being invited to participate/participated in a prescribed fire; (B) the entities that invited respondents to participate in a prescribed fire; $(C)$ the sources that respondents used to obtain information about prescribed fire.

\begin{tabular}{cccccc}
\hline (A) Participation Role & $\begin{array}{c}\text { Number } \\
\mathbf{( N = 6 2 )}\end{array}$ & (B) Inviting Entity & $\begin{array}{c}\text { Number } \\
\text { (N = 62) }\end{array}$ & $\begin{array}{c}\text { (C) Information } \\
\text { Source }\end{array}$ & $\begin{array}{c}\text { Number } \\
\mathbf{( N = 1 1 9 )}\end{array}$ \\
\hline Burn manager & 10 & NRCS & 16 & NRCS & 17 \\
Assistant & 14 & State Agencies & 16 & State Forest Service & 47 \\
Volunteer & 30 & Landowner & 45 & Fire Chief/EMS & 79 \\
Bystander & 12 & PBA & 10 & Colleagues & 27 \\
Other & 13 & Other & 13 & Other & 31 \\
Total responses * & 79 & Total responses * & 100 & Total responses * & 201 \\
\hline
\end{tabular}

NRCS: USDA Natural Resource Conservation Service; State Agencies: Texas Parks and Wildlife Department, Texas Forest Service, and Oklahoma Forest Service; PBA: Prescribed Burn Association; * Total responses is greater than $\mathrm{N}$-the number of respondents who answered the questions-because each respondent could select more than one response.

Of the responding Commissioners, $97 \%$ reported some familiarity with prescribed fire (Table 2), and the response patterns were not statistically different between Texas and Oklahoma (Fisher's Exact test $p=0.275$ ). Additionally, most Commissioners reported being comfortable with prescribed fire (84\% selected a positive score for "level of comfort," $83 \%$ selected a negative score for "level of discomfort," and 15\% selected neutral scores for both "level of comfort" and "level of discomfort"). Responses to the two statements representing comfort and discomfort with prescribed fire were negatively correlated (Pearson's coefficient $r=-0.52, p<0.001)$. We detected no statistically significant relationship between either level of comfort or discomfort and state of residence (Fisher's Exact test $p=0.948$ for comfort and $p=0.993$ for discomfort) or respondent location in a county with or without a Prescribed Burn Association (Fisher's Exact test $p=0.296$ for comfort and, $p=0.672$ for discomfort). Given that the levels of comfort and discomfort were strongly correlated, we selected the level of comfort as a variable for inclusion in models investigating our five objectives. We assess our five objectives in the next five subsections. 
Table 2. The distribution of Commissioners' self-reported familiarity with prescribed fire $(\mathrm{N}=123)$.

\begin{tabular}{cccccc}
\hline State & $\begin{array}{c}\text { Not Familiar } \\
\text { at All }\end{array}$ & $\begin{array}{c}\text { Slightly } \\
\text { Familiar }\end{array}$ & $\begin{array}{c}\text { Moderately } \\
\text { Familiar }\end{array}$ & $\begin{array}{c}\text { Very } \\
\text { Familiar }\end{array}$ & Total \\
\hline Texas & $4(5.0 \%)$ & $21(26.6 \%)$ & $33(41.8 \%)$ & $21(26.6 \%)$ & 79 \\
Oklahoma & $0(0.0 \%)$ & $15(34.1 \%)$ & $15(34.1 \%)$ & $14(31.8 \%)$ & 44 \\
Total & $4(3.2 \%)$ & $36(29.3 \%)$ & $48(39.0 \%)$ & $35(29.5 \%)$ & 123 \\
\hline
\end{tabular}

\subsection{Factors Influencing Decisions to Enact Burn Bans}

Of 124 respondents, only seven Commissioners (5.6\%) indicated they had never enacted a burn ban (Figure 1A). Time spent as a Commissioner was the only statistically significant predictor of enacting a burn ban. A one-year increase in time spent as a Commissioner increased the likelihood of having enacted a burn ban by $107 \%\left(\mathrm{z}_{110}=2.14\right.$, $p=0.031$ ). We could not assess the role of familiarity with fire or gender on whether commissioners have ever enacted a burn ban because these variables resulted in the quasicomplete separation, and therefore, the maximum likelihood for familiarity and gender could not be calculated. Two of the categories of familiarity perfectly predicted whether a commissioner enacted a burn ban (not familiar and somewhat familiar commissioners had all enacted burn bans). Similarly, all of the commissioners who had never enacted a burn ban were male. Firth's bias correction did not correct for separation when run for this model. Therefore, we left the problematic variables in the model because the quasi-complete separation has not been shown to affect the maximum likelihood estimates of other variables in the model, but leaving a separated variable out of a model has been shown to introduce omitted variable bias to the maximum likelihood estimates for other variables. Response patterns for both burn ban enactment and awareness of exemptions were similar in Texas and Oklahoma (Figure 1A). Thirty-six Commissioners (29\%) stated they were unaware of any exceptions for burning during a burn ban (Figure 1B) despite the fact that there are exceptions in both states. Awareness of exceptions did not differ between states but was influenced by their comfort with fire. Increasing comfort with fire by one unit increased the likelihood that a Commissioner would be aware of burn ban exemptions by $86 \%\left(z_{110}=2.05, p=0.049\right)$. Likelihoods are determined by odds ratios calculated from exponentiated log odds for a given dependent variable; all results of logistic models will be presented in the text as likelihoods derived from odds ratios for ease of interpretation, corresponding log odds outputs for each model are reported in the supplementary tables.

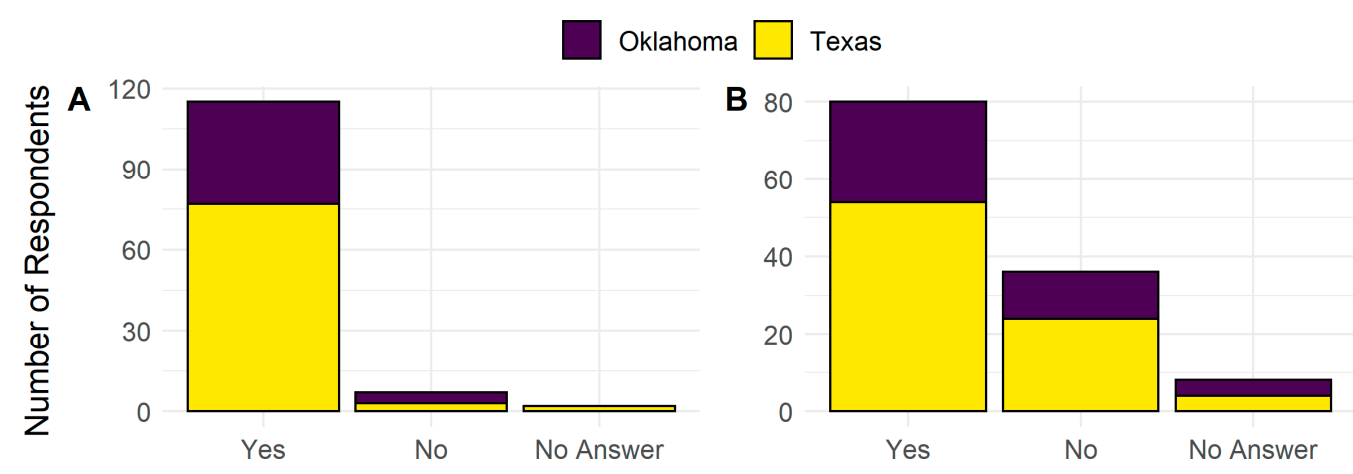

Figure 1. The number of respondents that (A) indicated they had placed a burn ban in their county and (B) stated they were aware of exceptions to burn bans in their county. Texas respondents are shown in yellow and Oklahoma in purple.

Holding all other variables constant, the likelihood of selecting a higher level of comfort with fire increased by $99 \%$ with each 1 step increase in familiarity with fire $\left(z_{108}=2.31\right.$, $p=0.022$ ), and the likelihood of selecting a higher comfort level increased by $136 \%$ if a Commissioner was a rural landowner $\left(\mathrm{z}_{95}=2.01, p=0.049\right)$. Most Commissioners (and all Oklahoma respondents) reported being at least slightly familiar with prescribed fire. 


\subsection{Criteria Used to Make Decisions Regarding Burn Bans}

Commissioners most commonly selected high fire danger according to an index as a criterion that must be met to enact a burn ban, followed by dangerous weather conditions and high fuel load; $32 \%$ of Commissioners indicated there were no criteria that needed to be met and Commissioners could enact burn bans at their discretion (Figure 2A). The tests for simultaneous pairwise marginal independence revealed no dependence between whether a Commissioner has enacted a burn ban and the criteria they selected for implementing burn bans $\left(\chi^{2}=2.9, \mathrm{df}=3.58, p=0.51\right.$; reported degrees of freedom for all tests for marginal independence are the degrees of freedom that were used in testing the second-order RaoScott adjusted Pearson statistic described in the methods section). Similarly, there was no association between awareness of exemptions for burning during burn bans and criteria necessary to enact burn bans $\left(\chi^{2}=4.11, \mathrm{df}=4.00, p=0.39\right)$. By contrast, there was an association at $p<0.10$ between familiarity with prescribed fire and the criteria identified as necessary to enact a burn ban $\left(\chi^{2}=24.18, \mathrm{df}=7.72, p=0.09\right)$. The contingency table revealed a relationship between being very familiar with prescribed fire and selecting high fire danger according to an index as a criterion for implementing a burn ban $\left(\chi^{2}=9.51\right.$, $p=0.03)$.

A

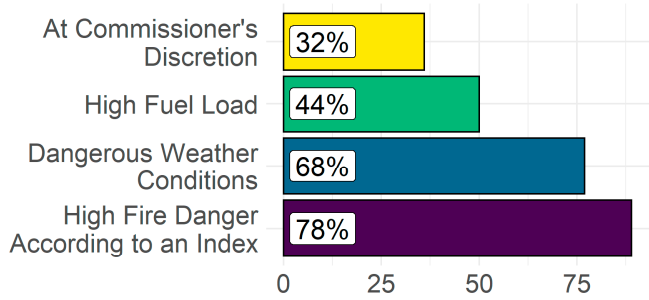

B

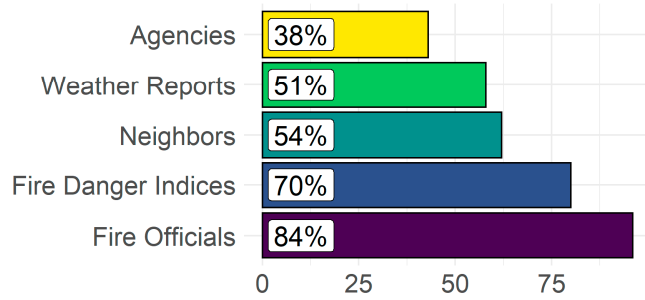

Figure 2. The number of respondents that (A) selected a particular category of criteria that must be met to enact a burn ban and (B) selected a particular category of information source they used in deciding to enact a burn ban. White labels show the percentage of all respondents who selected this category. They total more than $100 \%$ because respondents could select more than one category.

The most commonly selected information sources Commissioners used in determining whether to enact a burn ban were fire officials and fire danger indices. Agencies were selected least often as sources of information, with only 38\% of Commissioners identifying them as sources they use to make decisions regarding burn bans (Figure 2B). Tests for simultaneous pairwise marginal independence showed no statistically significant association between information sources selected and having enacted a burn ban $\left(\chi^{2}=2.56, \mathrm{df}=\right.$ $2.31, p=0.34)$ or awareness of exemptions for burning during a burn ban $\left(\chi^{2}=4.5, \mathrm{df}=\right.$ $3.29, p=0.24)$. There was an association at the $p<0.10$ level between information sources selected and familiarity with fire $\left(\chi^{2}=17.02, \mathrm{df}=10.74, p=0.098\right)$. Bonferroni-adjusted $\chi^{2}$ values for the contingency table combinations show that commissioners who reported they were very familiar with fire selected fire officials as a source of information more often than commissioners who selected any other category of familiarity $\left(\chi^{2}=8.6, p=0.04\right)$.

\subsection{The Role of Comfort with Prescribed Fire in Decision-Making}

Self-reported comfort with prescribed fire did not play a role in Commissioners' decisions to enact burn bans $\left(\mathrm{z}_{87}=0.22, p=0.83\right)$, but comfort was associated with their awareness of exemptions for burning during burn bans $\left(z_{58}=2.05, p=0.049\right)$. There was no association between comfort with prescribed fire and the criteria that must be met to enact burn bans $\left(\chi^{2}=3.14, \mathrm{df}=3.11, p=0.41\right)$ or information used in decision-making via burn bans $\left(\chi^{2}=1.13, \mathrm{df}=3.01, p=0.62\right)$.

\subsection{Thoughts Regarding Effect of a Shift in Liability Standard on Burn Ban Decisions}

Only $20 \%$ of the Commissioners thought that a shift in the liability standard that was applied to escaped prescribed fire cases in their state from simple negligence to gross negli- 
gence (a less stringent standard) would change the amount of pressure they would receive from the public to enact burn bans. Of those, about half thought it would increase the pressure, and half thought it would decrease the pressure. Whether a Commissioner thought pressure from the public would change if the liability standard changed was not related to the Commissioners' familiarity or comfort with fire or any of the demographic variables.

\subsection{Thoughts Regarding Effect of a Shift in Liability Standard on Frequency of Burn Bans}

Most Commissioners ( $\sim 67 \%)$ responded that a shift in the liability standard for escaped prescribed fire from simple to gross negligence would not alter the frequency with which they would enact burn bans. Of the $24 \%$ who stated that the frequency of burn ban enactment would likely change, about half thought the frequency would increase and half thought it would decrease, but that varied between states with more Oklahoma respondents stating they would enact fewer burn bans and more Texas respondents stating they would enact more burn bans. Commissioners' indication that a shift in the liability standard would change their frequency of burn ban enactment was not related to their familiarity or comfort with prescribed fire or any of the demographic variables. However, it was related to whether or not they felt that pressure from the public would change if the liability standard changed. Commissioners who thought that public pressure would change were $109 \%$ more likely to say that they would change the frequency with which they enacted burn bans $\left(\mathrm{z}_{92}=4.38, p=0.003\right)$.

\section{Discussion}

To maximize the benefits of applying prescribed fire to increase forage productivity and reduce wildfire risks, it is important to burn rangelands when invasive woody plants and accumulated fuel loads are most effectively reduced. The mortality of invasive woody plants in the Southern Plains of North America, especially Juniperus species, is generally maximized when fire intensity is high $[6,11,12]$. However, the hot and dry conditions under which such fire intensity occurs are commonly the same conditions that lead to the implementation of burn bans due to heightened concerns over escaped fire $[7,9]$.

In Texas and Oklahoma, County Commissioners are responsible for implementing and repealing countywide bans on outdoor burning [10]. As elected officials and residents of the communities they serve, Commissioners may feel pressure to implement and enforce burn bans because of public anxiety regarding prescribed fire safety $[9,37,38]$. While burn bans may be prudent for short-term reductions in escaped fires, they can also inhibit the use of prescribed fire for mitigating long-term wildfire risks. To better characterize this quandary, factors affecting the decision-making of Commissioners regarding burn bans need to be better understood. To fill this knowledge gap, we addressed five objectives, the results and implications of which are discussed below.

\subsection{Factors That Influence Commissioners' Decisions to Enact Burn Bans}

While we anticipated variability among commissioners in burn ban enactment because of variability in the acceptability of prescribed burning across the study region [38], most of the commissioners reported having enacted burn bans and only years served as a Commissioner correlated with the enactment of a burn ban. This comports with the finding that commissioners were selecting objective criteria for enacting burn bans. If a commissioner in TX or OK has served long enough, it is likely that their county will have weather conditions indicative of high fire danger at some point during their tenure. Another possible explanation for the lack of significance of other factors to explain burn ban enactment is that our respondents represented a fairly homogenous demographic group of individuals who had been in office for at least several years, owned rural land, and were more likely than non-respondents to be familiar with and to have participated in a prescribed fire. 


\subsection{Criteria Commissioners Use to Make Burn Ban Decisions}

Commissioners most commonly selected objective safety criteria to make decisions regarding burn bans. While this leads to greater predictability than making decisions without specific criteria, burn bans enacted during low-fuel moisture conditions inhibit the ability of managers to burn when conditions are conducive for high-intensity restoration burns [11]. The large proportion of commissioners who indicated that no criteria needed to be met to enact a burn ban, however, suggests that there might be cases where less objectivity in decision-making could further limit opportunities for restoration burns.

Commissioners most commonly relied on their local fire department, fire chief, or emergency management coordinator to obtain information about fire danger. Furthermore, to place a burn ban, Commissioners in Oklahoma are required to have "the documented [agreement] of a majority of the chiefs, or their designees, of the municipal and certified rural fire departments located in the county that a period of extreme fire danger exists" [17]. While we found no evidence that these entities influence Commissioners' burn ban decisions, local fire departments and emergency services may represent an important target group for outreach and education efforts about the benefits and relative safety of prescribed fire that is applied when they most effectively reduce invasive woody plants. These influential stakeholders may then be more likely to support Commissioners' decisions to permit burn ban exemptions during periods when prescribed fire most effectively mitigates wildfire risk $[22,39]$.

\subsection{Effect of Commissioners' Comfort Level with Prescribed Fire on Decisions}

When serving in an official capacity as an elected local official, regardless of their level of comfort with prescribed fire, Commissioners appeared to align their perspectives of prescribed fire with fire prevention and seemed inclined to pre-emptively enact burn bans and reluctant to approve exemptions to such bans when conditions are conducive for high-intense fires that most effectively suppress WPE and reduce accumulated fuel loads. This paradox is possibly due to the negative public perceptions about fire and the influence of emergency response personnel who focus on extinguishing the fire. This view of fire aligns with anti-fire norms, perceived liability, and little tolerance for management errors $[9,37,40]$.

The relatively advanced age of the respondents tends to be positively correlated with a person's networks in his or her place of residence [41], suggesting that many Commissioners have developed a strong sense of community with nearby landowners. Under such circumstances, social norms frequently influence decisions regarding land management, including the use of prescribed fire [37,42,43]. Furthermore, fostering community ties has served as a strong foundation for the formation of neighbor-helping-neighbor cooperatives that provide resources, education, encouragement, and empowerment. In the context of prescribed fire, Prescribed Burn Associations (PBAs) have been widely established to help members overcome liability concerns by providing training, equipment, and labor to apply prescribed fire safely $[7,39,44]$. The ability of PBAs to conduct fire when it is most effective for woody plant control could be enhanced by establishing close relationships with Commissioners and emergency service personnel and inviting them to attend prescribed fires conducted by their members. This could build trust among these officials in the ability of PBA members and burn managers to apply fire safely and, therefore, increase their receptiveness to deferring burn bans, allowing more burn ban exemptions.

\subsection{Effect of Shift from Simple to Gross Negligence on Pressure to Enact Burn Bans}

In most states where gross negligence applies, there are statutorily prescribed standards a burner must follow in order for the gross negligence standard to apply while burning outside of those standards will result in courts applying simple negligence in a resulting lawsuit [45]. States with gross negligence standards were found to have a higher frequency and scale of prescribed burning compared to neighboring states with simple negligence standards [45]. Based on these findings, we expected that Commissioners 
would indicate that a shift from simple to gross negligence would lead to more public pressure to enact burn bans as some of the risk is moved from burners to their neighbors under gross negligence [46], creating an impetus for non-burners to seek other limitations to their risk. However, only a quarter of the Commissioners in our study thought such a shift in negligence liability statutes would change public pressure to enact burn bans and, of those, only about half thought the pressure would increase. This suggests that most Commissioners feel public perceptions regarding prescribed fire risk will not be swayed by a shift in legal liability because such perceptions are often based on long-held opinions, media coverage of wildfires, or other socially determined ideas rather than a clear understanding of prescribed fire risk $[9,26,38]$.

This finding contrasts with a survey of District Court Judges regarding prescribed fire liability [47]. That study found that a shift toward a gross negligence liability standard for escaped fire cases might result in fewer findings of prescribed burner liability, especially in Texas. Therefore, even though most Commissioners responded that a shift in escaped fire liability to gross negligence would not change their decisions regarding burn bans, such a shift could nevertheless increase the use of prescribed fire by landowners because of the potential reduction in liability for escaped fire. However, the pro-fire culture in Oklahoma, which, similar to Texas, has a simple negligence statute for escaped fire [9], suggests that a shift in liability statute may not be a precondition for increasing the prevalence of prescribed fire, but rather that certain language within current statutes could be modified to decrease uncertainty about outcomes of lawsuits pertaining to escaped fire [48].

\subsection{Effect of Shift to Gross Negligence on Commissioners' Decision to Enact Burn Bans}

We also expected Commissioners to indicate that they would enact more burn bans following a change in escaped fire liability from simple to gross negligence because of increased pressure from the public. However, most respondents did not expect such a change to affect the frequency with which they would enact burn bans. Those who indicated that such a change would affect public pressure were much more likely to say they would change burn ban frequency, with more Oklahoma respondents indicating they would enact fewer burn bans and more Texas respondents indicating more burn bans. The implications of fewer burn bans in Oklahoma following the enactment of a lower liability standard is that the length of burn windows could increase, which could increase prescribed fire use, leading to more fuel load reduction and generally resulting in a more proactive fire culture. By contrast, the potential increase in burn ban enactment in Texas under a shift to gross negligence could further inhibit the application of prescribed fire to manage invasive woody plants, which would lead to more accumulated fuel loads for wildfires and a potential loss of function and integrity in grassland and savanna ecosystems. Since some Commissioners are responsive to pressure from their constituents, interaction with Commissioners by those seeking to use prescribed fire to control WPE could increase the willingness of Commissioners to grant exemptions to burn bans more readily.

\subsection{Limitations and Future Research}

While our pilot study provides some useful insights about Commissioners' familiarity and level of comfort with fire, criteria they would use to enact burn bans, and their perspectives about the effect of escaped fire liability standards on burn ban enactment, our study left many important questions unanswered. In part, this was due to the fact that our study did not capture a substantial number of Commissioners who were uncomfortable or unfamiliar with this wildfire mitigation tool. This was not a failing of the sample selection as we randomly selected the 400 Commissioners who were included in the study; however, our non-response bias analysis determined that responding Commissioners were statistically more familiar and comfortable with prescribed fire than non-respondents. It is possible that Commissioners who were less familiar with fire felt they had little to contribute to the study. Furthermore, our study was limited to two states in the Southern Plains. Input from officials tasked with implementing burning restrictions from other 
Great Plains states or other countries experiencing WPE would be important to provide a broader understanding of decision-making regarding the enactment of burn bans. While our study was geographically constrained, our findings may be informative for other fireprone regions of the US, as well as Mediterranean regions [49], Australia [50,51], Southern Africa [52], and other areas where fuel load accumulation and hot dry conditions present increasingly serious wildfire risks, but where officials who influence the use of fire may perceive this wildfire mitigation tool to carry a high level of risk. More studies in other regions of the world would help to determine if our findings regarding burn ban decisionmaking on the use of prescribed fire as a wildfire mitigation tool have broader applicability.

\section{Conclusions}

Most Commissioners surveyed in Texas and Oklahoma were comfortable with the use of prescribed fire but still indicated that they implemented burn bans during times of highfire danger as indicated by fire-danger indices and fire weather variables. This suppressionand prevention-related attitude toward prescribed burning could limit the window for burning when conditions are most conducive to reducing woody plant densities and lowering fire risk associated with the conversion of grass to woody fuels. The majority of Commissioners obtained information about prescribed fire from their local fire departments or emergency services, making these groups a target audience for prescribed fire outreach and education efforts. Further, the most influential contributing factor to Commissioners' comfort with prescribed fire was their degree of self-reported familiarity with the practice. Since comfort with prescribed fire was associated with awareness of exemptions for burning during burn bans, those who wish to promote and implement prescribed fire for the restoration of woody plant encroached rangelands and wildfire reduction could improve the likelihood of obtaining an exemption to burn during a burn ban by actively involving Commissioners in the use of prescribed fire. Relationships based on trust in the ability of PBAs and associated burn managers to start a fire safely, even during burn ban conditions, may ease Commissioners' and emergency service personnel concerns regarding prescribed fire, allowing them to feel comfortable granting burn ban exemptions. This will provide managers more flexibility in applying prescribed fire as a restoration and wildfire mitigation tool when it will most effectively meet their management objectives.

Supplementary Materials: The following are available online at https://www.mdpi.com/article/10 $.3390 /$ land10070686/s1.

Author Contributions: Conceptualization, C.L.W., M.L.T. and U.P.K.; methodology, C.L.W., M.L.T. and U.P.K.; formal analysis, T.W.M. and C.L.W.; data curation, T.W.M.; writing-original draft preparation, T.W.M., C.L.W., M.L.T. and U.P.K.; project administration, U.P.K.; funding acquisition, C.L.W., M.L.T. and U.P.K. All authors have read and agreed to the published version of the manuscript.

Funding: This research was funded by the Joint Fire Sciences Program, grant number 16-1-02-10.

Data Availability Statement: The data from this study are available on request from the corresponding author. The data are not publicly available to protect the anonymity of survey respondents.

Conflicts of Interest: The authors declare no conflict of interest.

\section{References}

1. Pyne, S.J. Fire: A Brief History; University of Washington Press: Seattle, WA, USA, 2001; 204p.

2. Axelrod, D.I. Rise of the grassland biome, central North America. Bot. Rev. 1985, 51, 163-202. [CrossRef]

3. Archer, S. Woody Plant Expansion into Southwestern Grasslands and Savannahs: Rates, Patterns, and Proximate Causes. In Ecological Implications of Livestock Herbivory in the West; Vavra, M., Laycock, W., Pieper, R., Eds.; Society for Range Management: Denver, CO, USA, 1994; pp. 13-68.

4. Fuhlendorf, S.D.; Townsend, D.W., II; Elmore, R.D.; Engle, D.M. Pyric herbivory to promote rangeland heterogeneity: Evidence from small mammal communities. Rangel. Ecol. Manag. 2010, 63, 670-678. [CrossRef]

5. Fuhlendorf, S.D.; Archer, S.R.; Smeins, F.E.; Engle, D.M.; Taylor, C.A., Jr. The combined influence of grazing, fire, and herbaceous productivity on tree-grass interactions. In Western North American Juniperus Communities: A Dynamic Vegetation Type; Van Auken, O.W., Ed.; Springer: New York, NY, USA, 2008. 
6. Twidwell, D.; Rogers, W.E.; Fuhlendorf, S.D.; Wonkka, C.L.; Engle, D.M.; Weir, J.R.; Kreuter, U.P.; Taylor, C.A. The rising Great Plains fire campaign: Citizens' response to woody plant encroachment. Front. Ecol. Environ. 2013, 11, 64-71. [CrossRef]

7. Ryan, K.C.; Knapp, E.E.; Varner, J.M. Prescribed fire in North American forests and woodlands: History, current practice, and challenges. Front. Ecol. Environ. 2013, 11, e15-e24. [CrossRef]

8. Van Liew, D.; Conner, J.R.; Kreuter, U.P.; Teague, W.R. An economic assessment of prescribed extreme fire and alternative methods for managing invasive brush species in Texas: A modeling approach. Open Agric. J. 2012, 6, 17-26. [CrossRef]

9. Twidwell, D.; Fuhlendorf, S.D.; Taylor, C.A.; Rogers, W.E. Refining Thresholds in Coupled Fire-Vegetation Models to Improve Management of Encroaching Woody Plants in Grasslands. J. Appl. Ecol. 2013, 50, 603-613. [CrossRef]

10. Brooks, D.B. Guide to Texas Laws for County Officials; Texas Association of Counties: Austin, TX, USA, 2018.

11. Twidwell, D.; Rogers, W.E.; Wonkka, C.L.; Taylor, C.A., Jr.; Kreuter, U.P. Extreme prescribed fire during drought reduces survival and density of woody resprouters. J. Appl. Ecol. 2016, 53, 1585-1596. [CrossRef]

12. Weir, J.R.; Kreuter, U.P.; Wonkka, C.L.; Twidwell, D.; Stroman, D.A.; Russell, M.; Taylor, C.A., Jr. Liability and prescribed fire: Perception and reality. Rangel. Ecol. Manag. 2019, 72, 533-538. [CrossRef]

13. Matonis, M.S. Insights and Suggestions for Certified Prescribed Burn Manager Programs. Forest Stewards Guild. Available online: https: / / foreststewardsguild.org/wp-content/uploads/2020/03/InsightsRecommendationsCPMBprograms.pdf (accessed on 9 July 2020).

14. Texas Department of Agriculture. Certified and Insured Prescribed Burn Managers: Requirements for Certification. Available online: https:/ / www.texasagriculture.gov/Home/ProductionAgriculture/PrescribedBurnProgram/CommercialCertifiedPrescri bedBurnManager.aspx (accessed on 10 November 2019).

15. Texas Natural Resources Code Ann. § 6.153.048. 2009. Available online: https://statutes.capitol.texas.gov/Docs/NR/htm/NR. 153.htm (accessed on 10 November 2019).

16. Texas Department of Agriculture. Information \& Resources for Counties during Burn Bans. Available online: https:// www.texasagriculture.gov/Home/ProductionAgriculture/PrescribedBurnProgram/BurningDuringaBurnBan.aspx (accessed on 10 November 2019).

17. Oklahoma State Legislature. Oklahoma Statutes § 2.16.26. Available online: http://www.oklegislature.gov/osStatuesTitle.aspx (accessed on 23 April 2021).

18. Oklahoma SIP: OK 252:100-13 Prohibition of Open Burning. Available online: https://www.epa.gov/sips-ok/oklahoma-sip-ok252100-13-prohibition-open-burning (accessed on 23 April 2021).

19. McCaffrey, S. Prescribed fire: What influences public approval? In Fire in Eastern Oak Forests: Delivering Science to Land Managers; Gen Tech Rep, NRS-P-1; Dickinson, M.B., Ed.; USDA Forest Service, Northern Research Station: Newtown Square, PA, USA, 2006.

20. Toman, E.; Stidham, M.; Shindler, B.; McCaffrey, S. Reducing fuels in the wildland-urban interface: Community perceptions of agency fuels treatments. Int. J. Wildland Fire 2011, 20, 340-349. [CrossRef]

21. Shindler, B.A.; Toman, E.; McCaffrey, S.M. Public perspectives of fire, fuels and the Forest Service in the Great Lakes Region: A survey of citizen-agency communication and trust. Int. J. Wildland Fire 2009, 18, 157-164. [CrossRef]

22. Cortner, H.J.; Zwolinski, M.J.; Carpenter, E.H.; Taylor, J.G. Public support for fire-management policies. J. For. 1984, 82, 359-361.

23. Harr, R.N.; Morton, L.W.; Rusk, S.R.; Engle, D.M.; Miller, J.R.; Debinski, D. Landowners' perceptions of risk in grassland management: Woody plant encroachment and prescribed fire. Ecol. Soc. 2014, 19, 19. [CrossRef]

24. Bendel, C.; Toledo, D.; Hovick, T.; McGranahan, D. Using behavioral change models to understand private landowner perceptions of prescribed fire in North Dakota. Rangel. Ecol. Manag. 2020, 73, 194-200. [CrossRef]

25. Jacobson, S.K.; Monroe, M.C.; Marynowski, S. Fire at the wildland interface: The influence of experience and mass media on public knowledge, attitudes, and behavioral intentions. Wildl. Soc. Bull. 2001, 29, 929-937.

26. Twidwell, D.; Wonkka, C.L.; Sindelar, M.T.; Weir, J.R. First approximations of prescribed fire risks relative to other management techniques used on private lands. PLoS ONE 2015, 10, e0140410. [CrossRef] [PubMed]

27. Samson, F.; Knopf, F. Prairie conservation in North America. BioScience 1994, 44, 418-421. [CrossRef]

28. Samson, F.B.; Knopf, F.L.; Ostlie, W.R. Great Plains ecosystems: Past, present, and future. Wildlife Soc. Bull. 2004, 32, 6-15. [CrossRef]

29. Dillman, D.A.; Smyth, J.D.; Christian, L.M. Internet, Phone, Mail, and Mixed-Mode Surveys: The Tailored Design Method; Wiley: Hoboken, NJ, USA, 2014.

30. Rubin, D.B. Multiple Imputation for Nonresponse in Surveys; John Wiley and Sons: New York, NY, USA, 1987.

31. Barnard, J.; Rubin, D.B. Small sample degrees of freedom with multiple imputation. Biometrika 1999, 86, 948-955. [CrossRef]

32. Bilder, C.; Loughin, T.M. Testing for marginal independence between two categorical variables with multiple responses. Biometrics 2004, 60, 241-248. [CrossRef]

33. R Core Team. R: A Language and Environment for Statistical Computing; R Foundation for Statistical Computing: Vienna, Austria, 2018; Available online: https:/ / www.r-project.org/ (accessed on 10 November 2019).

34. Van Buuren, S.; Groothuis-Oudshoorn, K. Mice: Multivariate Imputation by Chained Equations in R. J. Stat. Softw. $2011,45,1-67$. Available online: https:/ /www.jstatsoft.org/v45/i03/ (accessed on 10 November 2019). [CrossRef]

35. Venables, W.N.; Ripley, B.D. Modern Applied Statistics with S, 4th ed.; Springer: New York, NY, USA, 2002.

36. Koziol, N.; Bilder, C. MRCV: Methods for Analyzing Multiple Response Categorical Variables (MRCVs). R Package Version 0.3-3. Available online: https:/ /CRAN.R-project.org/package=MRCV (accessed on 10 November 2019). 
37. Toledo, D.; Sorice, M.G.; Kreuter, U.P. Social and Ecological Factors Influencing Attitudes toward the Application of HighIntensity Prescribed Burns to Restore Fire Adapted Grassland Ecosystems. Ecol. Soc. 2013, 18, 9. Available online: http: //www.ecologyandsociety.org/vol18/iss4/art9/ (accessed on 10 November 2019). [CrossRef]

38. Kreuter, U.P.; Stroman, D.A.; Wonkka, C.; Weir, J.; Abney, A.A. Landowner perceptions of legal liability for using prescribed fire in the Southern Plains, USA. Rangel. Ecol. Manag. 2019, 72, 959-967. [CrossRef]

39. Taylor, C.A. Prescribed Burning Cooperatives: Empowering and Equipping Ranchers to Manage Rangelands. Rangelands 2005, 27, 18-23. [CrossRef]

40. North, M.P.; Stephens, S.L.; Collins, B.M.; Agee, J.K.; Aplet, G.; Franklin, J.F.; Fulé, P.Z. Reform forest fire management: Agency incentives undermine policy effectiveness. Science 2015, 349, 1280-1281. [CrossRef]

41. Wilkinson, D. Individual and community factors affecting psychological sense of community, attraction, and neighboring in rural communities. Can. Rev. Soc. 2008, 45, 305-329. [CrossRef]

42. Schubert, J.R.; Mayer, A.L. Peer influence of non-industrial private forest owners in the Western Upper Peninsula of Michigan. Open J. For. 2012, 2, 150-158. [CrossRef]

43. Lind-Riehl, J.; Jeltema, S.; Morrison, M.; Shirkey, G.; Mayer, A.L.; Rouleau, M.; Winkler, R. Family Legacies and Community Networks Shape Private Forest Management in the Western Upper Peninsula of Michigan (USA). Land Use Policy 2015, 45, 95-102. [CrossRef]

44. Toledo, D.; Kreuter, U.P.; Sorice, M.G.; Taylor, C.A., Jr. The role of prescribed burn associations in the application of prescribed fires in rangeland ecosystems. J. Environ. Manag. 2014, 132, 323-328. [CrossRef]

45. Wonkka, C.L.; Rogers, W.E.; Kreuter, U.P. Legal barriers to effective ecosystem management: Exploring linkages between liability, regulations, and prescribed fire. Ecol. App. 2015, 25, 2382-2393. [CrossRef]

46. Yoder, J. Liability, regulation, and endogenous risk: The incidence and severity of escaped prescribed fires in the United States. J. Law Econ. 2008, 51, 297-325. [CrossRef]

47. Hinojosa, A.; Wonkka, C.L.; Kreuter, U.P. Liability and the use of prescribed fire in the Southern Plains, USA: A survey of District Court Judges. Land 2020, 9, 318. [CrossRef]

48. Yoder, J. Playing with Fire: Endogenous Risk in Resource Management. Am. J. Agr. Econ. 2004, 86, 933-948. [CrossRef]

49. Kalabokidis, K.; Iosifides, T.; Henderson, T.M.; Morehouse, B. Wildfire policy and use of science in the context of a socio-ecological system on the Aegean Archipelago. Env. Sci. Policy 2008, 11, 408-421. [CrossRef]

50. Altangerel, K.; Kull, C.A. The Prescribed burning debate in Australia: Conflicts and compatibilities. J. Environ. Plan. Manag. 2013, 56, 103-120. [CrossRef]

51. Moskwa, E.; Bardsley, D.K.; Robinson, G.M.; Weber, D. Generating narratives on bushfire risk and biodiversity values to inform environmental policy. Environ. Sci. Policy 2018, 89, 30-40. [CrossRef]

52. Brown, P.J.; Manders, P.T.; Bands, D.P. Prescribed burning as a conservation management practice: A case history from the Cedar Berg Mountains, Cape Province, South Africa. Biol. Conserv. 1991, 56, 133-150. [CrossRef] 